PP-405

前立腺肥大症の detrusor instabilityに 対する Ice Water Test の意

\section{奈良県立医科大学 泌尿器科}

松本 吉弘, 平山暁秀, 商田 聡, 岡息 英二郎, 吉井 将人 趙 順規, 藤本 清秀, 植村 天受, 大園 諴一郎, 平尾 佳彦 【目的】前立腺肥大症における刺激症状の病態を解明するた めに、Ice Water Test(IWT)を行いIWT 陽性例の臨床症 状と尿水力学的検查の相関を検討し、C fiber の関与を評価した。【対象と方法】排尿障害で受診し、pressure flow study (PFS) および IWTを施行した前立腺肥大 症 38 例 (平均年齢 67.5 歳)を对象とした。IWTは $0^{\circ} \mathrm{C}$ の生 理食塩水を膀胱内人 $100 \mathrm{ml}$ 注入し、膀胱内压が $15 \mathrm{cmH}_{2} \mathrm{O}$ 以上上昇した症例を陽性とした。これらの症例におけるIWT の結果と前立腺肥大症の重症度評価項目、UDS 結果などの パラメーターを解析し、BPH 症例におけるIWT の特徵およ び臨床症状に与える影啫を検討した。結果】Detrusor instability（DI）は $42 \%$ に、IWT陽性は $21 \%$ に認め、IWT隄 性例はすべて DI を認めた。IWT 陽性例は、臨床像からみて 尿意切迫を訴える症例が多く、PFSにおいて下部尿路閉塞 度が高く、機能的膀脱容星および最大尿意出現時の膀脱容 量の低下を認めた。結語】以上の結果から、前立腺肥大症 の頻尿発現の一因として、下部尿路閉塞による慢性的な高圧 排尿によりC fiberを介する経路が活性化され、機能的膀胱 容量が減少することが示唆された。

前立䁶肥大症 detrusor instability lce Water Test

\section{PP-406}

前立腺肥大症に対するタムスロシンとナフ トピジルによる治療効果の検討

\section{浜松労災病院 泌尿器科}

西澤 恒二, 小林 恭, 小倉 敬司

【目的】タムスロシンとナフトピジルによる治療を行った前立腺 肥大症症例につき、治療効果を検討した。方法】対象は 2000 年 5 月から 2001 年 10 月までの期間で、 $\alpha 1$ ブロッカー 内服治療を行った末治療前立腺肥大症 59 症例。うち夕ムス ロシン内服治療 40 例( $\mathrm{T}$ 群)ナフトピジル内服治療 19 例 (N 群)であった。治療開始 6 ヶ月後までの治療効果を、IPSS、 QOL スコア、Qmaxにて評価した。前立腺肥大症治䪭效果 判定基準により治療効果を判定した。成維】治療前の前立 腺体皘の平均值 \pm SD は、39.4 $17.7 \mathrm{ml}$. IPSS は 19.1 26.2 、 QOL スコアは 4.5 $1.0 、 \mathrm{Qmax}(\mathrm{ml} / \mathrm{s})$ は $11.4 \pm 5.2$ で、T 群と $\mathrm{N}$ 群に有意差はなかった。治療後 $\mathrm{T}$ 群・ $\mathrm{N}$ 群各々の IPSSの 平均值 $\mathrm{SSD}$ は、13.5 $56.6 、 12.6 \pm 6.8 、 \mathrm{QOL}$ スコアは $3.4 \pm 1.4$ 、 $3.2 \pm 1.2 、 \mathrm{Qmax}$ は $12.5 \pm 4.4 、 13.4 \pm 5.2$ と改善、両群で治療効 果に有意差はなかった。N 群では治療有効群で、治療前の IPSS 刺激症状スコアが有意に高かった。結論】 リンレセプター選択性のタムスロシンと $\alpha 1 \mathrm{~d}$ アドレナリンレセブ ター選択性のナフトピジルで、治療効果に差はなかった。ナフト ピジルでは下部尿路刺激症㧋が強いほうが治療有効であっ た。

前立䠌肥大症 $\alpha 1 \mathrm{a}$ ブロッカー $\alpha 1 \mathrm{~d}$ ブロッカー

\section{PP-407}

前立腺肥大症に对するナフトピジルと塩酸 タムスロシンの臨床効果の比較検的一先行 薬鼡無効例に対する他剤への切り替え効 果-

\section{東京医科亩科大学 大学院 尿路生殖譏能学(汹尿器科)} 林哲夫, 奥野 哲男, 增田 均, 鈴木 理仁, 酒井 康之 小林 甽, 川上 理,藤井 埥久,兵地 信彦, 新井 学 碳藤一隆, 影山幸雄, 木原和徳

【目的】前立腺肥大症の治療として、ナフトピジルおよび塩酸夕 ムスロシンを同一患者に投与し、両凧の臨床効果の相違を検討 した。【対象・方法】ナフトピジル 50-75mgを 4 週間以上投与し QOL スコアの改善が得られなかった 85 名の患者に対し塩酸夕 ムスロシン 0.1-0.2mgを 8 週間投与した。また、塩酸タムスロシ ン 0.1-0.2mgを 4 週間投与し QOL スコアの改善が得られな かった 89 名の患者にナフトピジル 50-75mgを 8 週間以上投 与して 2 郕の効果を比較検討した。先行薬剂開始前、楽剤変 更時、変更後 8 週間後に、IPSS、QOL スコア、最大尿流量率、 残尿量を測定した。結果】ナフトピジル無効群で塩酸夕ムスロ シンを 8 週間投与することによって尿意切迫感、尿勢の低下、腹 王排尿が有意に改善した。塩酸タムスロシン無効群でナフトピジ ルを 8 週間投与することによって残尿感、間歇排尿、夜間頻尿 が有意に改善した。結論】 1 ブロッカーは、それぞれに効果が 異なっており,塭酸夕ムスロシンは尿勢の改善に倎れた効果があ り、ナフトピジルは夜間頻尿に優れた効果があった。 前立腺肥大症 ナフトピジル 塩酸タムスロシン

\section{PP-408 精神疾患を有する前立腺肥大症患者の治 療について}

浅香山病院 泌尿器科" 浅香山病院 泌尿器科2) 済生 会奈良病院 泌尿器科 ${ }^{3}$ 奈良祡立医科大学 泌尿器科4 守屋 昭", 山本 広明 ${ }^{2}$, 川上隆", 石橋 道男 ${ }^{4}$

大園 誠一郎"

【目的】当院は、959 床の精神科病棟が併設されており、泌尿 器疾患を合併する患者も少なくない。今回、精神科病棟に入 院中で、前立腺肥大症 (BPH) と診断された患者について、そ の治療方法及び治療成経を検討した。【方法】2001 年 8 月よ り 2001 年 10 月に当科を受診した、精神科入院中の BPH 患 者 51 名について、日本泌尿器科学会排尿障害臨床試験力 イドラインに従って、BPH の重症度別、治療別に治療成績を 検討した。また、精神疾患分類は、米国精神医学会精神疾患 の分類と診断の手引き(DSM 分類)を用い、精神状態の安定 度は、陽性陰性症状評価尺度(PANSS)を使用した。【結果】 年齡は50歳～ 87 歳、平均 62.7 藏。精神疾患は分裂病 47 名、簿病 3 名、疾呆 1 名で、PANSS スコアーは平均 3 以下 であった。BPH の重症度は軽症 5 名、中等症 36 名、重症 10 名であった。治療方法は、薬物療法を全例、ILCPを 5 名、 TUR-Pを 3 名に施行した。治療効果は、有効以上が、手術 群ではほほ100\%であった。結論】精神状態が安定してい れば、薬物療法も含め、良好な治療効果が期待できると考え られた。 前立腺肥大症 精神疾患 